This is a postprint version of the following published document:

A.M. Martos; M. Herrero; A. Várez; B. Levenfeld.

Synthesis and characterization of new membranes based on sulfonated polysulfone/Zn,Al-heptamolibdate LDH. Materials Letters, 152 (Aug. 2015), pp. 125-127

(c) 2015 Elsevier B.V. All rights reserved.

DOI: $\underline{10.1016 / \text { j.matlet.2015.03.094 }}$ 


\title{
Synthesis and characterization of new membranes based on sulfonated polysulfone/Zn,Al-heptamolibdate LDH
}

\author{
A.M. Martos, M. Herrero, A. Várez, B. Levenfeld* \\ Department of Materials Science and Engineering, University Carlos III of Madrid, Avda. Universidad 30, 28911 Leganés, Madrid, Spain
}

\begin{abstract}
A B S T R A C T
New proton conducting organic/inorganic nano hybrid polymer electrolyte membranes were synthe sized by solving casting method. Inorganic nanopowders were a layered double hydroxides (LDH) with $\mathrm{Zn}, \mathrm{Al}$ cations in which heptamolybdate were inserted. These nanopowders were prepared by anion exchange method from hydrotalcite $(\mathrm{LDH})$ with interlayer anions $\left(\mathrm{NO}_{3}\right)$. The sulfonated polymers were prepared by an electrophilic aromatic substitution reaction between the polymer and trimethylsylil cholorosulfonate (TMSCS).

The composites membranes were characterized by FTIR and TGA and water uptake was determined. Electrochemical impedance spectroscopy (EIS) was used to study the proton conductivity of the membranes. EIS measurements were performed facing the membrane to different $\mathrm{HCl}$ concentrations $\left(10^{3} \leq c \leq 10^{1} \mathrm{M}\right)$. It was concluded that these new composite membranes present good thermal properties and proton conductivity slightly higher than SPSU.
\end{abstract}

Keywords:

Sulfonated polysulfone

Layered double hydroxide

Heptamolybdate

Polymer exchange membranes

Fuel cells the basic properties of LDH and will provide higher proton mobility in

Perfluorinated polymers, such as Nafion, are the most widely used electrolyte in proton exchange membrane fuel cell (PEMFC) due to its high proton conductivity, excellent mechanical properties and good chemical and electrochemical stability. However, this type of membrane also exhibits some drawbacks, mainly the high cost, low stability at high temperatures, low conductivity at low humidity [1] or high temperature and high methanol crossover. For this reason, there are many efforts to find alternatives to these perfluorinated membranes $[2,3]$.

Polysulfone (PSU) has attracted considerable interest due to its excellent thermal and mechanical stability, low cost and commercial availability. In particular, sulfonated polysulfone (SPSU) ionomer membranes have been extensively studied and tested for fuel cell applications $[4,5]$. In order to increase some properties of polymers, different inorganic fillers, such as, $\mathrm{TiO}_{2}$ [6], $\mathrm{ZrO}_{2}$ [7], phosphoanti monic acid [4], etc, were incorporated in SPSU.

Recently, we have prepared sulfonated polysulfone (SPSU)/layered double hydroxide ( $\mathrm{LDH}$ ) composite membranes, in which the con ductivity was improved [8]. Herein, we present the synthesis and characterization of new SPSU composites membranes with nanopow ders of $\mathrm{Zn}, \mathrm{Al} \mathrm{LDH}$ intercalated with a heptamolibdate, $\left(\mathrm{NH}_{4}\right)_{6} \mathrm{Mo}_{7} \mathrm{O}_{24}$. The heteropolyacid, which is a strong Brönsted type acid, will minimize

\footnotetext{
* Corresponding author. Tel.: + 34 916249915; fax: + 34916249430

E-mail address: bll@ing.uc3m.es (B. Levenfeld).
}

the composite membrane.

\section{Experimental section}

Firstly, the sulfonation process was carried out in anhydrous conditions under $\mathrm{N}_{2}$ following the method described by Chao et al. [9]. The solution of polysulfone (PSU) in 1,2 dichloroethane was treated with trimethylsilyl chlorosulfonate, $\mathrm{Si}\left(\mathrm{CH}_{3}\right)_{3} \mathrm{SO}_{3} \mathrm{Cl}$ (TMSCS) diluted in 1,2 dichloroethane $\left(\mathrm{C}_{2} \mathrm{H}_{4} \mathrm{Cl}_{2}, \mathrm{DCE}\right)$ and was maintained under magnetic stirring during $24 \mathrm{~h}$ at room temperature. Once the reaction was over, the sulfonated polymer was purified until neutral $\mathrm{pH}$. Finally, the obtained polymer was dried at room temperature. The molar ratio of PSU: TMSCS was 1:3 and the sulfonation degree determined from ${ }^{1} \mathrm{H}$ NMR experiments was 0.77 .

The synthesis of $\mathrm{Zn}, \mathrm{Al} \mathrm{NO}_{3}$ (LDH) was carried out by the co precipitation method $[8,10]$. Thus, the solution of with $\mathrm{Zn}: \mathrm{Al}$ molar ratio of 2, prepared with $\mathrm{Zn}\left(\mathrm{NO}_{3}\right)_{2} \cdot 6 \mathrm{H}_{2} \mathrm{O}$ and $\mathrm{Al}\left(\mathrm{NO}_{3}\right)_{3} \cdot 9 \mathrm{H}_{2} \mathrm{O}$, were added drop wise to a solution of $1 \mathrm{M} \mathrm{NaOH}$, with stirring and the $\mathrm{pH}$ was maintained at 8.0. Afterward, intercalation of $\left(\mathrm{NH}_{4}\right)_{6} \mathrm{Mo}_{7} \mathrm{O}_{24}$ were performed following Ref. [11]. The solution of $\left(\mathrm{NH}_{4}\right)_{6} \mathrm{Mo}_{7} \mathrm{O}_{24}(1.1 \mathrm{~g}$ of $\left(\mathrm{NH}_{4}\right)_{6} \mathrm{Mo}_{7} \mathrm{O}_{24}$ in $50 \mathrm{ml}$ of decarbonated water) was added drop wise to the $\mathrm{LDH}$ solution ( $1 \mathrm{~g}$ of $\mathrm{LDH}$ in $150 \mathrm{ml}$ of decarbonated water) under $\mathrm{N}_{2}$ atmosphere and a constant $4.5 \mathrm{pH}$. The reaction mixture was stirred for a $24 \mathrm{~h}$ at $60{ }^{\circ} \mathrm{C}$. The intercalation reaction was confirmed by XRD. The particle size of the powder is highly agglomerated as observed by 
SEM. The crystalline size determined by XRD using Scherrer equation and peak (lllll 002 ) was $7.9 \mathrm{~nm}$.

Finally, membrane preparation was carried out. In this last step, dried sulfonated PSU was dissolved (5 wt\%) in DMAc. Afterward, the HMo LDH particles were suspended in the polymer solution during $3 \mathrm{~h}$ with mechanical stirring and $1 \mathrm{~h}$ in an ultrasonic bath. Finally the solutions were cast on Petri glass dish and dried in the oven at $60{ }^{\circ} \mathrm{C}$ for $48 \mathrm{~h}$ and at $120^{\circ} \mathrm{C}$ for $24 \mathrm{~h}$. The obtained membranes were immersed in water to eliminate possible traces of solvent and, then, dried at room temperature. The amount of HMo LDH in the compo site membrane was from 1 to $5 \mathrm{wt} \%$. The thickness of membranes was around $100 \mu \mathrm{m}$.

Once prepared the membrane, a fully characterization of the films were carried out. Infrared spectra were recorded with a Perkin Elmer Spectrum GX FTIR spectrometer in the $4000400 \mathrm{~cm}^{1}$ range. Thermal characterization of membranes was performed by thermo gravimetric analysis (Perkin Elmer Pyris TGA1). The analyses were performed between 50 and $900{ }^{\circ} \mathrm{C}$ at a heating rate of $10^{\circ} \mathrm{C} / \mathrm{min}$ under air flow. Water uptake of all composite membrane samples was determined at room temperature, by immersion in deionized water during 72 h, using Eq. (1):

Water uptake $=\left(\left(W_{\text {wet }} W_{\text {dry }}\right) / W_{\text {dry }}\right) \times 100$

$W_{\text {wet }}$ and $W_{\text {dry }}$ correspond to the weights of membranes in wet and dry state, respectively.

The proton conductivity measurements were performed in a liquid test cell constituted by two half cells using ac impedance technique. The membrane was sandwiched between two o rings. A conventional electrochemical setup of four electrodes was used for these measurements involving two saturated $\mathrm{Ag} / \mathrm{AgCl}$ electro des (reference electrodes) and two graphite electrodes (secondary electrodes). The measurements were conducted at room tempera ture in an impedance/gain phase analyser (Solartron 1260) and an electrochemical interface (Solartron 1287). The frequency range was $1 \mathrm{MHz} 10 \mathrm{~Hz}$. Six different $\mathrm{HCl}$ solutions $\left(10^{3} \leq c \leq 0.1 \mathrm{M}\right)$ were tested.

\section{Results and discussion}

FT IR analysis: Sulfonation process of the polysulfone was qualitatively confirmed by FTIR. The results indicated clearly the presence of sulfonic groups in the polymer backbone after sulfo nation reaction (Fig. 1). In the frequency range of $10501000 \mathrm{~cm}{ }^{1}$ two characteristic peaks were observed [6]. In particular, the band located at $1014 \mathrm{~cm}^{1}$ was assigned to the symmetric stretching vibration of the diphenylether unit, while the peak at $1028 \mathrm{~cm}{ }^{1}$ is due to the symmetric stretching vibration of the sulfonated group [12]. In the case of composite membranes, this characteristic shoulder of SPSU at $1028 \mathrm{~cm}^{1}$ is slightly shifted to higher values

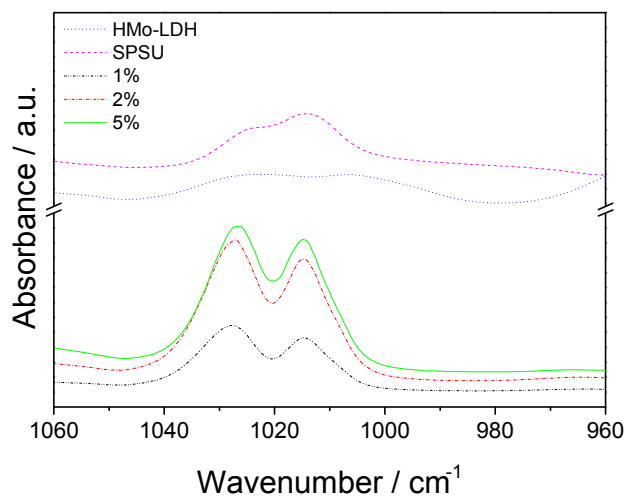

Fig. 1. FTIR spectra of SPSU, HMo-LDH and SPSU with 1,2,5\% of HMo-LDH. of wavenumber when inorganic filler increase, indicating weak interactions between the hydroxyl HMo LDH layer and the sulfo nic group, probably due to hydrogen bonding. Furthermore, the intensity of this shoulder increased with the content of $\mathrm{HMo} \mathrm{LDH}$, indicating remarkable interaction between the HMo LDH and the SPSU.

Thermogravimetric analysis (TGA): The thermal stability of SPSU and composite membranes was studied by TGA (Fig. 2). SPSU membranes exhibited three weight losses: (i) between 50 and $250{ }^{\circ} \mathrm{C}$ corresponds to absorbed water bonded to sulfonic groups, (ii) between 250 and $450{ }^{\circ} \mathrm{C}$, attributed to the desulfonation pro cess and (iii) above $450{ }^{\circ} \mathrm{C}$ related to the main chain decomposi tion [13].

TGA curves of HMo LDH powder present two weight losses: between 50 and $175{ }^{\circ} \mathrm{C}$ corresponds to adsorbed water and the second one $\left(175400{ }^{\circ} \mathrm{C}\right)$ was attributed to the dehydroxilation of HMo LDH [11]. The presence of HMo LDH modifies slightly the thermal stability of the membranes. In all the cases, the desulfona tion and main chain decompositions are delayed with the presence of the HMo LDH. The degradation of the main chain of the polymer (above $450{ }^{\circ} \mathrm{C}$ ) depends on the amount of HMo LDH, being fully degraded at temperature less than $750{ }^{\circ} \mathrm{C}$ for membranes with 1 and $2 \%$ of HMo LDH and in the case of the sample with $5 \%$, the degradation is similar to that of SPSU alone.

Water uptake: The water uptake at room temperature of membranes with different percentages of HMo LDH was evalu ated. The amounts of absorbed water decreased as the HMo LDH increases (Fig. 3, right axis). These results are in agreement with the TGA analysis in the low temperature range $\left(50175^{\circ} \mathrm{C}\right)$. This behavior was found in other composite membrane system [14] and it was attributed to the reduction of the free volume and swelling ability.

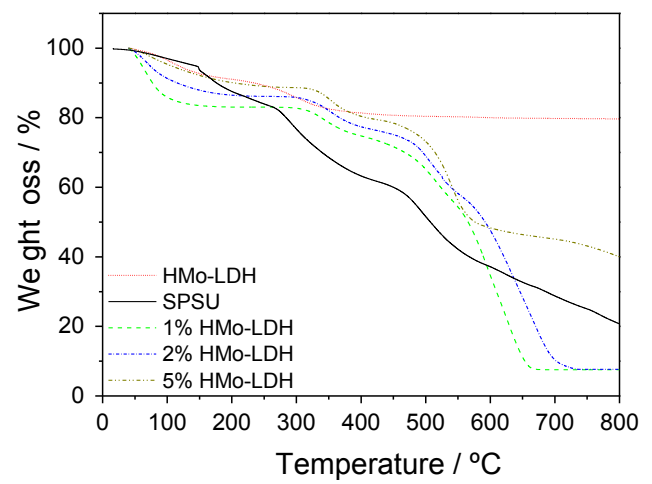

Fig. 2. Thermogravimetric analysis of HMo-LDH, SPSU and their respective HMoLDH composites.

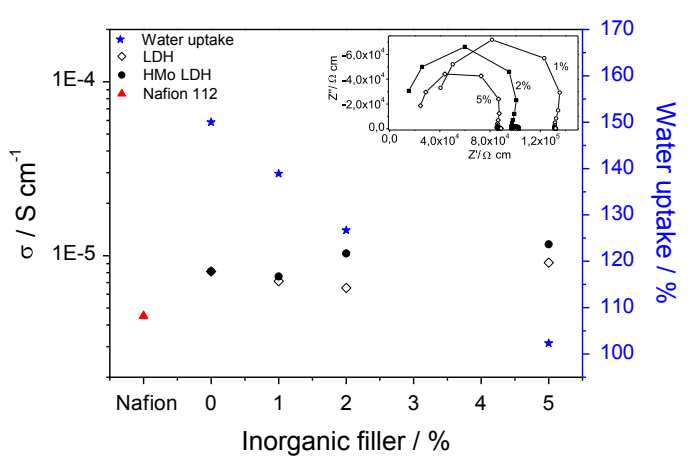

Fig. 3. Water uptake $(\star)$ and conductivity of SPSU/HMo-LDH hybrid composite membranes with the inorganic filler. In the inset the Nyquist plots are plotted. Values are also compared with nanocomposites of SPSU/LDH [8]. 
Proton conductivity: The proton conductivity was performed using electrochemical impedance spectroscopy (EIS). All mem branes were placed in contact with different acid concentrations $\left(10^{3} \leq c \leq 0.1 \mathrm{M}\right)$ during a specific period of time. As expected Nyquist plots changed with the $\mathrm{HCl}$ concentration (data do not shown) and it was attributed to the concentration dependence of the electrolyte solution embedded in the membrane matrix $[8,15]$.

The evolution of the conductivity with the amount of HMo LDH is showed in Fig. 3, left axis. This value was obtained from the intercept on the real axis at the high frequency end of the Nyquist plot (inset of Fig. 3). The conductivity values increases with the amount of HMo LDH and it is slightly higher than nanocomposites membranes of SPSU/LDH [8].

\section{Conclusions}

A new class of organic/inorganic nano hybrid polymer electrolyte membranes based on sulfonated polysulfone and heptamolybdate inserted in layered double hydroxide nanocomposite membranes were prepared.

The presence of HMo LDH in the membranes was confirmed by FTIR. The introduction of HMo LDH improved the thermal beha viour. The conductivity of composite membranes is in the same range of the SPSU and slightly increases with the inorganic filler. These results indicated that HMo LDH/SPSU nanocomposites mem branes are very promising for being applied as proton exchange membranes.

\section{Acknowledgements}

This work has been supported by the Projects from the regional government (Comunidad de Madrid through MATERYENER3CM S2013/MIT 2753) and Spanish Government, MINECO (MAT2013 46452 (4 3R).

\section{References}

[1] Di Noto V, Negro E, Sanchez J-Y, Iojoiu C. Structure relaxation interplay of a new nanostructured membrane based on tetraethylammonium trifluoromethanesulfonate ionic liquid and neutralized Nafion 117 for hightemperature fuel cells. J Am Chem Soc 2010;132:2183-95.

[2] Peighambardoust SJ, Rowshanzamir S, Amjadi M. Review of the proton exchange membranes for fuel cell applications. Int J Hydrogen Energy 2010;35:9349-84.

[3] Lufrano F, Baglio V, Staiti P, Arico AS, Antonucci V. Polymer electrolytes based on sulfonated polysulfone for direct methanol fuel cells. J Power Sources 2008;179:34-41.

44] Genova-Dimitrova P, Baradie B, Foscallo D, Poinsignon C, Sanchez JY. Ionomeric membranes for proton exchange membrane fuel cell (PEMFC): sulfonated polysulfone associated with phophatoantimonic acid. J Membr Sci 2001;185:59-71.

[5] Kerres J, Ullrich A, Meier F, Häring T. Synthesis and characterization of novel acid-base polymer blends for application in membrane fuel cells. Solid State Ionics 1999; 125:243-9.

[6] Devrim Y, Erkan S, Bac N, Eroglu I. Preparation and characterization of sulfonated polysulfone/titanium dioxide composite membranes for proton exchange membrane fuel cells. Int J Hydrogen Energy 2009;34:3467-75.

[7] Navarra MA, Croce F, Scrosati B. New high temperature superacid zirconiadoped Nafion composite membranes. J Mater Chem 2007;17:3210-5.

[8] Herrero M, Martos AM, Várez A, Galván JC, Levenfeld B. Synthesis and characterization of polysulfone/layered double hydroxides nanocomposite membranes for fuel cell application. Int J Hydrogen Energy 2014;39:4016-22.

[9] Chao SY, Elsey DR. Process for preparing sulfonated poly(arylether) resins. United States patent US 4,625,000. 1996 Nov 25.

[10] Gardner E, Pinnavaia TJ. On the nature of selective olefin oxidation catalysts derived from molybdate- and tungstate-intercalated layered double hydroxides. Appl Catal A 1998;167:65-74.

[11] Carriazo D, Domingo C, Martín C, Rives V. Structural and texture evolution with temperature of layered double hydroxides intercalated with paramolybdate anions. Inorg Chem 2006;45:1243-51.

[12] Iulianelli A, Clarizia G, Gugliuzza A, Ebrasu D, Bevilacqua A, Trotta F, et al. Sulfonation of PEEK-WC polymer via chloro-sulfonic acid for potential PEM fuel cell applications. J Hydrogen Energy 2010;35:12688-95.

[13] Kim KS, Lee KH, Cho K, Park CE. Surface modification of polysulfone ultrafiltration membrane by oxygen plasma treatment. J Membr Sci 2002;199(1-2):135-45.

[14] Kalappa P, Lee JH. Proton conducting membranes based on sulfonated poly (ether etherketone)/ $/ \mathrm{TiO}_{2}$ nanocomposites for a direct methanol fuel cell. Polym Int 2007;56:371-5.

[15] Benavente J, Cañas A, Ariza MJ, Lozano AE, De Abajo J. Electrochemical parameters of sulfonated poly-ether ether sulfone/membranes in $\mathrm{HCl}$ solutions determined by impedance spectroscopy and membrane potential measurements. Solid State Ionics 2001;145:53-60. 